Review

\title{
Fugitive Dust Suppression in Unpaved Roads: State of the Art Research Review
}

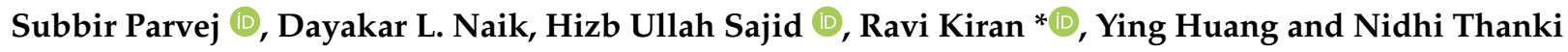 \\ Department of Civil \& Environmental Engineering, North Dakota State University, Fargo, ND 58105, USA; \\ msubbir.parvej@ndsu.edu (S.P.); dayakarnaik.lavadiya@ndsu.edu (D.L.N.); hizbullah.sajid@ndsu.edu (H.U.S.); \\ ying.huang@ndsu.edu (Y.H.); nidhi.thanki@ndsu.edu (N.T.) \\ * Correspondence: ravi.kiran@ndsu.edu
}

check for updates

Citation: Parvej, S.; Naik, D.L.; Sajid H.U.; Kiran, R.; Huang, Y.; Thanki, N. Fugitive Dust Suppression in Unpaved Roads: State of the Art Research Review. Sustainability 2021, 13, 2399. https://doi.org/10.3390/ su13042399

Academic Editor: Paolo S. Calabrò

Received: 24 December 2020

Accepted: 12 February 2021

Published: 23 February 2021

Publisher's Note: MDPI stays neutral with regard to jurisdictional claims in published maps and institutional affiliations.

Copyright: (c) 2021 by the authors. Licensee MDPI, Basel, Switzerland. This article is an open access article distributed under the terms and conditions of the Creative Commons Attribution (CC BY) license (https:/ / creativecommons.org/licenses/by/ $4.0 /)$.

\begin{abstract}
Fugitive dust is a serious threat to unpaved road users from a safety and health point of view. Dust suppressing materials or dust suppressants are often employed to lower the fugitive dust. Currently, many dust suppressants are commercially available and are being developed for various applications. The performance of these dust suppressants depends on their physical and chemical properties, application frequency and rates, soil type, wind speed, atmospheric conditions, etc. This article presents a comprehensive review of various available and in-development dust suppression materials and their dust suppression mechanisms. Specifically, the dust suppressants that lower the fugitive dust either through hygroscopicity (ability to absorb atmospheric moisture) and/or agglomeration (ability to cement the dust particles) are reviewed. The literature findings, recommendations, and limitations pertaining to dust suppression on unpaved roads are discussed at the end of the review.
\end{abstract}

Keywords: dust stabilizer; hygroscopicity; agglomeration; gravel roads; road visibility

\section{Introduction}

In the United States, unpaved or gravel roads constitute about $33.1 \%$ of the complete road network [1]. A significant portion of these unpaved roads serve as a connection between rural farming communities and urban areas, and the rest of them facilitate pathways to forests, mining fields, and timber hauls [2]. On unpaved roads, fugitive dust emanates from the mechanical interaction between the moving vehicles and the crushed aggregates [3]. Fugitive dust primarily comprises soil minerals (e.g., oxides of silicon, aluminum, calcium, and iron) with particulate material sizes lower than $10 \mu \mathrm{m}\left(\mathrm{PM}_{10}\right)$ [4]. According to the National Transportation Statistics (NTS) report [1], approximately 18.5 million short tons of $\mathrm{PM}_{10}$ and 5.34 million short tons of $\mathrm{PM}_{2.5}$ particulates (size lower than $2.5 \mu \mathrm{m}$ ) are entrained into the air annually. About $35 \%$ of this particulate material comes from unpaved roads [5]. From the health, economic, and safety points of view, the generation of fugitive dust poses a serious threat to road users and people living in the vicinity of unpaved roads.

The presence of $\mathrm{PM}_{10}$ and $\mathrm{PM}_{2.5}$ in the fugitive dust is found to significantly impact the health of the public, livestock, vegetation, and aquatic life in the premises of unpaved roads by promoting the transport of allergens, spores, and microorganisms [6,7]. While some researchers reported a positive association between $\mathrm{PM}_{2.5}$ particulates and the cardiovascular and respiratory complications [8-14], other researchers reported a positive association between $\mathrm{PM}_{10}$ and higher rates of hospitalization due to ischemic heart disease and carcinoma [15-17]. A more detailed literature review on various chronic diseases resulting from the fugitive dust can be found elsewhere [18-21]. In a recent data analysis carried out by $\mathrm{Wu}$ et al. [22] using data from the United States, a positive association between the long-term exposure to $\mathrm{PM}_{2.5}$ and the increased risk of COVID-19 (Coronavirus disease 2019) was reported, i.e., an increase of only $1 \mu \mathrm{g} / \mathrm{m}^{3}$ in $\mathrm{PM}_{2.5}$ is associated with an $8 \%$ increase in the COVID-19 death rate in the United States. In the case of children 
and elderly people, the finer dust particulates were noticed to aggravate heart and lung diseases such as bronchitis, pneumonitis, wheezing, cardiac artery disease, and cardiac arrhythmias, which can increase the risk of death [23].

When spread in air in higher concentrations, fugitive dust not only adversely impacts the air quality but also obscures the road visibility, leading to the increased risk of accidents, fatalities, and disruption of smooth flow of traffic $[4,24,25]$. The rate of fatalities on unpaved rural roads in the United States was reported to be more than double when compared to paved urban roads, i.e., for 100 million vehicle miles traveled, the rate of fatalities on unpaved rural roads is 1.8 , and the rate of fatalities on paved rural roads is $0.7[1,26]$. The probability of wind-related accidents was determined to contribute to low visibilities, indicating fugitive dust as one of the possible reasons for this increased accident rate on unpaved roads [6]. Examples of some accidents that occurred in the past due to fugitive dust include a chain of vehicle crashes on I-39 Wisconsin [27]; accidents on Interstate 5 in Coalinga, California; a fatal ATV rollover crash in Carlton country, Minnesota [28]; crashes in the intersection of Conejo Avenue and Highway 41, California [29]; crashes on U.S. Highway 87 between Great Falls and Fort Benton [30]; and accidents in Butler County, Missouri [30]. Numerous individual car crashes and mortalities were also recorded in the past on unpaved roads due to the low visibility and dust storms.

Keeping in view the dreadful impacts of fugitive dust on human health and safety, state departments of transportation (DoTs) and local (county/city/rural) agencies often employ maintenance techniques on these unpaved roads, such as paving, blading, speed control, and chemical stabilization to circumvent the entrainment of fugitive dust and to ensure the safety of unpaved road users [24]. Among these techniques, dust suppressants or chemical stabilizers are most widely adopted in practice due to their ease of application and low cost. The commonly employed dust suppressants to control the fugitive dust include water, calcium chloride $\left(\mathrm{CaCl}_{2}\right)$, magnesium chloride $\left(\mathrm{MgCl}_{2}\right)$, and other chloride salts. However, the performances of the dust suppressants vary depending on their physical and chemical characteristics, application rates, soil type, wind speed, atmospheric conditions, etc. Presently, there are more than 200 dust-suppressing products available on the market [31].

To the best of our knowledge, a comprehensive review of contemporary research into the dust-suppressing materials and their working mechanisms is not available in the literature. While it is necessary to understand the characteristics and the working mechanism of dust-suppressing materials from the field application perspective, it is also important to be informed about the process involved in synthesizing the material briefly that would be of interest for many practicing environmental, structural, and transportation engineers. The current review paper not only focuses on describing various working mechanisms involved in suppressing dust using dust suppressants but also provides a brief overview of the process involved in their synthesis. The rest of the manuscript is organized as follows. Description of the dust suppression mechanisms is provided in Section 2; a review of various categories of dust suppressants, their synthesis, and advantages are described in Section 3; and the highlights from the review and the recommendations are provided in Section 4.

\section{Dust Suppression Mechanisms}

The efficiency of dust suppressants is based on one or both of two underlying mechanisms, namely, hygroscopicity and agglomeration. In this section, a brief description of these two mechanisms is provided.

\subsection{Hygroscopicity}

Hygroscopicity refers to the ability of a solid substance to absorb or adsorb moisture from the surrounding atmosphere $[32,33]$. Owing to their affinity to water, hygroscopic substances can retain moisture and maintain a dampened, hard, and compact road surface, which subsequently prevents the erosion of fugitive dust. On the basis of the mechanism 
of water absorption, one can categorize the hygroscopic materials into two classes, namely, chemical and physical hygroscopic materials [34-36]. While chemical hygroscopic materials absorb water via a chemical reaction that converts their entire nature (e.g., metal hydrides), the physical hygroscopic materials imbibe water vapor through the following four mechanisms: (i) surface adsorption, (ii) condensation in capillaries (e.g., soft polyurethane sponge), (iii) reversible changes of the crystal structure (e.g., silica gel and anhydrous inorganic salt), and (iv) combination of capillary forces and hydration of functional groups (e.g., hydrogels and superabsorbent polymers). The detailed description of these mechanisms can be found elsewhere [37]. Interestingly, a hygroscopic substance may deliquesce if its critical relative humidity (CRH) is lower than that of the surrounding atmosphere, i.e., the water adsorbed on the surface of the hygroscopic substance starts to solvate molecules to an extent that the complete substance is liquified [32,38,39]. Often, deliquescent substances (e.g., $\mathrm{CaCl}_{2}, \mathrm{MgCl}_{2}, \mathrm{FeCl}_{2}$ etc.) are employed in practice for dust suppression [40]. The mechanism of dust suppression through hygroscopicity involves four stages (see Figure 1a), namely, Stage 1: the deliquescent dust suppressant is sprayed or mixed with the dust particles; Stage 2: deliquescent substance starts to absorb moisture, and water molecules start to accumulate around the deliquescent substance; Stage 3: the outer layer of the deliquescent substance gets dissolved in the absorbed water; and Stage 4: most of the deliquescent substance gets dissolved in the absorbed water that also contains the dust particle in the formed solution, thereby capturing the dust.

(a)

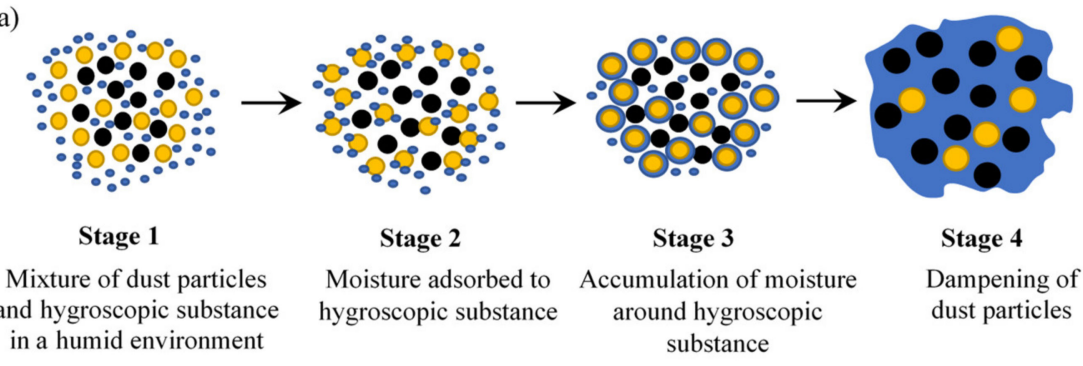

(b)

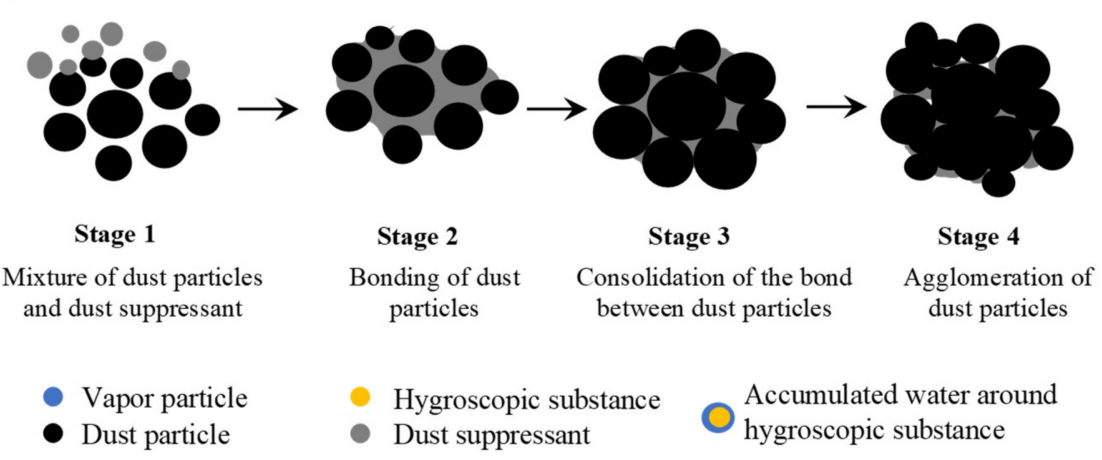

Figure 1. Schematic of dust suppression mechanisms: (a) hygroscopicity and (b) agglomeration.

\subsection{Agglomeration}

Agglomeration-based dust suppression is obtained when binding or cementing agents are introduced into the dust particles. Agglomeration is referred to as the process of converting small diameter solid particles into larger diameter granules that are composed of smaller particles. The binding or cementing agent introduces adhesive forces among the particles to accumulate a larger number and mass of smaller particles. As the mass of agglomerated particles increase, the constituent dust particles are less prone to become airborne. Examples of agglomeration-based dust suppressants include corn starch hydrogels, guar gum, chitosan, different surfactants, and oil-based substances. Similar to hygroscopicity, the mechanism of dust suppression through agglomeration involves four stages (see Figure 1b), namely, Stage 1: the dust suppressant is applied on the top layer of 
the unpaved road; Stage 2: the dust suppressant starts to form an adhesive bridge among the dust particles; Stage 3: the adhesive bridge starts to solidify between the dust particles; and Stage 4: the lump of the agglomerated dust particles grow in size, thus suppressing fugitive dust. However, agglomeration can take place on the top surface only where the agglomerated particles create a protective layer that resists the particles underneath it to become fugitive.

\section{Review of Various Dust Suppressants}

Dust suppressants have been categorized into three major types: (1) organic compoundbased, (2) biopolymer and chemical combination, and (3) inorganic compound-based dust suppressants (see Figure 2). Herein, a review of various dust suppressants and their performances, as reported in the literature, is presented. Specifically, the synthesis, application protocol, dust suppression mechanism, advantages, and hazards of various dust suppressants belonging to each group are described.

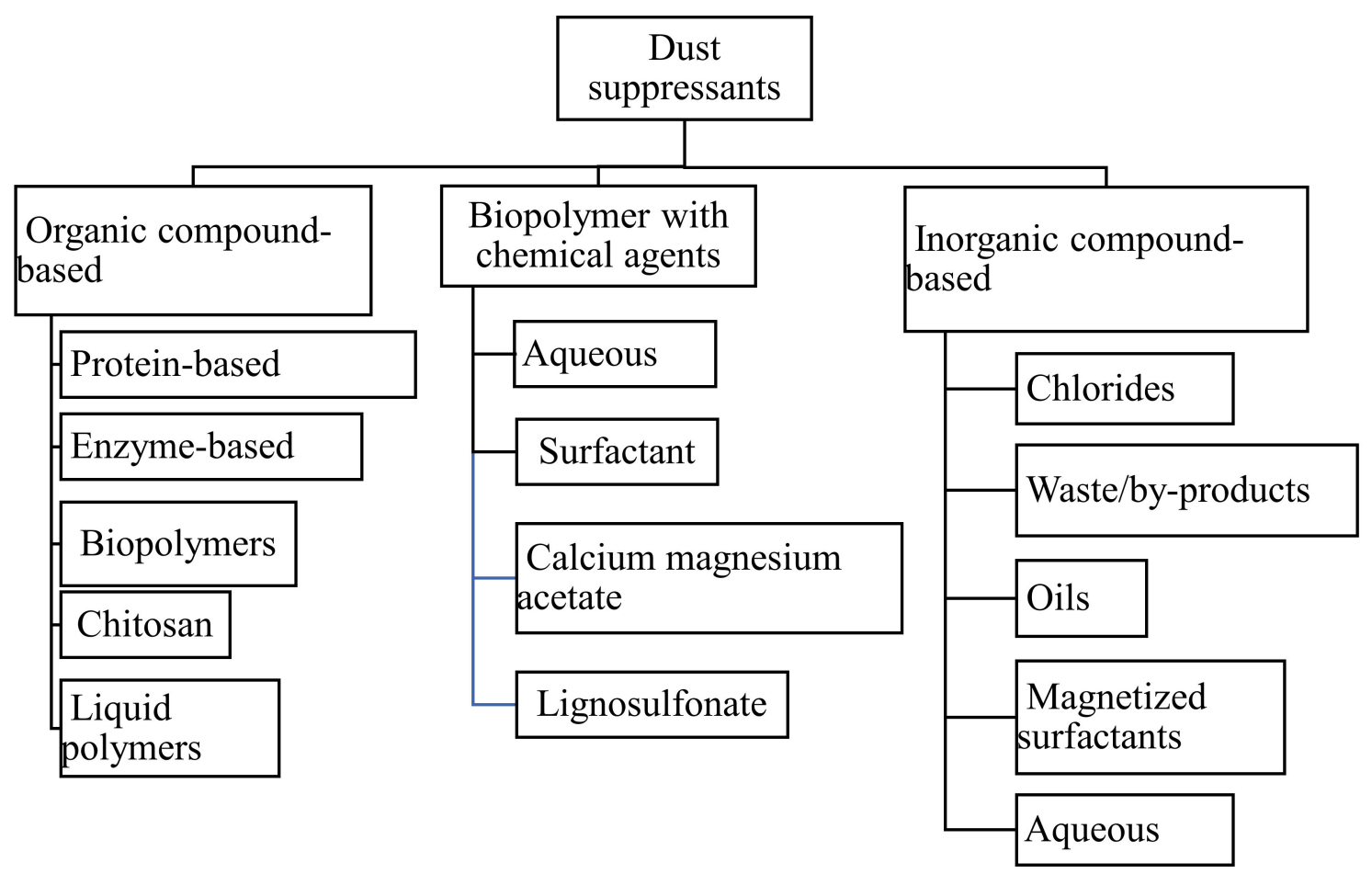

Figure 2. Flow chart of different classes of dust suppressants.

\subsection{Organic Compound-Based Dust Suppressants}

Organic compound-based dust suppressants primarily consist of organic compounds that are extracted from plants, bacteria, fungi, etc., and are biodegradable in nature. Although not used as stand-alone suppressants, the organic dust suppressants may intermittently be coupled with synthetic polymers to enhance the dust suppression performance. Examples of the organic compound-based dust suppressants that are commonly employed in practice include lignosulfonate, chitosan, guar gum, xanthan gum, and corn starch. Besides the biodegradability, the other major advantages possessed by the organic dust suppressants include abundant availability, low flammability, less corrosivity, less toxicity, and increased solubility in water. In this section, a brief literature review of the above-mentioned organic dust suppressants is provided. Specifically, the synthesis process, their working mechanism, and the effectiveness in suppressing the dust is highlighted (see Table 1). 
Table 1. Review of organic dust suppressants used for suppressing the dust.

\begin{tabular}{|c|c|c|c|c|c|c|c|c|}
\hline Type & Reference & $\begin{array}{c}\text { Dust } \\
\text { Suppressant }\end{array}$ & Dust Sources & Mechanism & Test & $\begin{array}{c}\text { Dust } \\
\text { Reduction/ } \\
\text { Emission Rate }\end{array}$ & Merits & Demerits \\
\hline $\begin{array}{l}\text { Protein- } \\
\text { based }\end{array}$ & $\begin{array}{l}\text { Jin et al. [41] } \\
\text { John Usher [44] }\end{array}$ & $\begin{array}{c}\text { SDS-SPI } \\
\text { Molasses protein }\end{array}$ & $\begin{array}{l}\text { Coal } \\
\text { Quarries, mine } \\
\text { sites, and building } \\
\text { sites }\end{array}$ & $\begin{array}{l}\text { Agglomeration } \\
\text { Agglomeration }\end{array}$ & $\begin{array}{c}\text { Lab test } \\
-\end{array}$ & $92.13 \%$ & $\begin{array}{l}\text { Eco-friendly, } \\
\text { biodegradability, and } \\
\text { pollution-free }[41,42]\end{array}$ & High cost [43] \\
\hline $\begin{array}{l}\text { Enzyme- } \\
\text { based }\end{array}$ & $\begin{array}{l}\text { David Gilmour } \\
\text { [45] } \\
\text { Zhan et al. [46] } \\
\text { Hamdan et al. [48] }\end{array}$ & $\begin{array}{c}\text { Bacteria-based } \\
\qquad \mathrm{CCL} \\
\text { EICP }\end{array}$ & $\begin{array}{l}\text { Mine road } \\
\text { Fugitive dust } \\
\text { Ottawa F-60 silica } \\
\text { sand, Arizona silty } \\
\text { fine sand, and } \\
\text { mine tailings }\end{array}$ & $\begin{array}{l}\text { Agglomeration } \\
\text { Agglomeration }\end{array}$ & $\begin{array}{l}\text { Field test } \\
\text { Lab test }\end{array}$ & $\begin{array}{c}0.3 \mathrm{mg} / \mathrm{m}^{3} \\
-\end{array}$ & $\begin{array}{l}\text { Safer in freeze } \\
\text { condition [45], } \\
\text { environment } \\
\text { friendliness, and } \\
\text { ecologically } \\
\text { compatibility [46] }\end{array}$ & $\begin{array}{l}\text { Frequent application required; high } \\
\text { maintenance cost of unpaved roads; } \\
\text { sophisticated initial production, } \\
\text { preservation, and application [45]; } \\
\text { negative impact of urea from EICP } \\
\text { on wildlife [47] }\end{array}$ \\
\hline \multirow{4}{*}{ Biopolymers } & Dang et al. [49] & OCS & $\mathrm{PM}_{2.5}$ and $\mathrm{PM}_{10}$ & Agglomeration & Lab test & $\begin{array}{l}68 \% \text { for } \mathrm{PM}_{2.5} \\
79 \% \text { for } \mathrm{PM}_{10}\end{array}$ & \multirow{4}{*}{$\begin{array}{c}\text { Environmental } \\
\text { friendliness, } \\
\text { cost-effectiveness, and } \\
\text { biodegradability [50] }\end{array}$} & \multirow{4}{*}{$\begin{array}{l}\text { Frequent application required and } \\
\text { fast decomposition }\end{array}$} \\
\hline & Bao et al. [50] & $\begin{array}{l}\text { PDS } \\
\text { Co-polymerized } \\
\text { cornstarch }\end{array}$ & Coal & $\begin{array}{l}\text { Agglomerationand } \\
\text { hygrocopicity } \\
\text { Agglomeration }\end{array}$ & Lab test & $1.2 \%$ per $3 \mathrm{~h}$ & & \\
\hline & Chen et al. [52] & Guar gum & $\begin{array}{l}\text { Mine tailings } \\
\text { (M.T.s) }\end{array}$ & Agglomeration & Lab test & $4 \mathrm{~g} / \mathrm{m}^{3}$ & & \\
\hline & Zhang et al. [53] & GGTCS & Coal & Agglomeration & Lab test & - & & \\
\hline \multirow{2}{*}{ Chitosan } & Liu et al. [54] & HTCC & Coal & Agglomeration & Lab test & $95.20 \%$ & $\begin{array}{l}\text { Biodegradability and } \\
\text { non-toxicity [55] }\end{array}$ & \multirow[t]{2}{*}{ Poor water solubility [54] } \\
\hline & Raab et al. [55] & $\begin{array}{l}\text { Poly (METAS)- } \\
\text { chitosan }\end{array}$ & Any sandy surface & Agglomeration & - & - & & \\
\hline $\begin{array}{l}\text { Liquid } \\
\text { polymer }\end{array}$ & Lee et al. [56] & PEG & $\mathrm{PM}_{2.5}$ and $\mathrm{PM}_{10}$ & Agglomeration & Lab test & $\begin{array}{l}86 \% \text { for } \mathrm{PM}_{2.5} \\
87 \% \text { for } \mathrm{PM}_{10}\end{array}$ & $\begin{array}{l}\text { Biocompatibility, easy } \\
\text { adaptability, and } \\
\text { eco-friendliness [56] }\end{array}$ & $\begin{array}{c}\text { Risk of secondhand pollution due to } \\
\text { decomposition of PEO-PPO-PEO } \\
\text { and PEG }\end{array}$ \\
\hline
\end{tabular}




\subsubsection{Protein-Based Dust Suppressants}

Protein-based dust suppressants possess the inherent ability of water retention, which can induce agglomeration in the dust particles and create a dense matrix of dust particles, making them less susceptible to become airborne [41]. Furthermore, they form a hardened shell layer that adheres to the dust particles. Protein-based dust suppressants can be a viable option for high dust areas such as quarries, mine sites, and building sites. Andrew et al. [43] were the first to introduce protein-based dust suppressants derived from molasses. The dust suppressant consists of water, concentrated molasses solids (CMS), and condensed molasses solids. Optionally, a wetting agent could also be added to facilitate the application of the dust suppressant to hydrophobic surfaces. Concentrated molasses solid is the desugared molasses byproduct obtained during the refining process of sugar and molasses, and the condensed molasses solids are obtained after the fermentation of molasses and the distillation of alcohol. Inspired by Andrew et al., Usher [44] utilized dunder, i.e., a byproduct of the sugar and/or molasses refining processes, to synthesize a dust suppressant concentrate with a lower content of protein.

Jin et al. [41] investigated a dust suppressant by modifying soy protein isolate (SPI) with an anionic surfactant, namely, sodium dodecyl sulfonate (SDS), in the presence of other additives, i.e., carboxymethylcellulose sodium and methanesiliconic acid sodium [41]. An ideal concentration of SPI was found to enhance the ability of the protein suppressant to cement the coal powder particles. At 3\% SDS-SPI solution concentration, the dust suppressant efficiency reached $92.13 \%$ when compared to untreated samples, and the dust suppressant also lowered the water evaporation rate. Additionally, the viscosity of the $3 \%$ concentration of SDS-SPI was found to be $12.96 \mathrm{mPa} . \mathrm{s}$, which met the requirements for use in coal mines.

When compared to lignosulfate (L.S.) dust suppressants, protein-based dust suppressants are claimed to be eco-friendly, biodegradable, and pollution-free [41,42]. However, protein-based dust suppressant materials are used in a lower number of applications because of their high cost [43].

\subsubsection{Enzyme-Based Dust Suppressants}

Enzyme-based dust suppressants are a relatively new class of dust suppressants. Gilmour [45] and Zhan et al. [46] synthesized bacterial enzyme-based organic dust suppressants to lower fugitive dust. On the other hand, Hamdan and Kanazanjian used the enzyme released by microbes to precipitate carbonates, thereby suppressing dust particles [48]. The dust suppressant developed by Gilmour [45] is composed of liquid glycerin, water, a natural polymer, and hydrocarbon-degrading bacteria. When the hydrocarbon is degraded by the enzymes of the bacteria, natural polymers are released from it that agglomerate the dirt particles, binding them into bigger particles. On the basis of the pilot study, the research concluded that the road surface treated with this dust controller using a spray bar and a pump yielded dust emissions as low as $0.3 \times 10^{-6} \mathrm{~kg} / \mathrm{m}^{3}$.

Zhan et al. employed a bacterium named Paenibacillus mucilaginosus to synthesize a dust suppressant [46]. The bacteria under a controlled lab environment were cultivated in a sucrose culture. After the cultivation, the bacteria were converted into a powder form by freeze-drying and were mixed with calcium nitrate. The bacteria absorb carbon dioxide from the atmosphere and form bicarbonate ions using an enzyme. The bicarbonate ions eventually transform to carbonate ions that attract calcium ions in the soil and attach them to the cell wall of the bacteria. Thus, the bacteria cell surfaces work as nucleation sites and agglomerate more particles around it. The agglomeration suppresses the fugitive dust by forming calcite and calcite-consolidated layers (CCL). The performance of CCL layers after two cycles of rainfall-induced erosion was also assessed. More than $90 \%$ of residual hardness ratio was recorded with the application of different concentration (normality $(\mathrm{N})$ ) of CCL, i.e., $1 \mathrm{~N}, 2 \mathrm{~N}$, and $3 \mathrm{~N}$, indicating good erosion resistance. A surface morphology analysis of CCL by X-ray diffraction (XRD) and scanning electron microscopy (SEM) characterization corroborated the formation of calcite and the cementation of the fugitive 
dust particles. Additionally, the comparison of SEM-based characterization between CCL and biological carbonate-based cementitious materials were presented. Note that the latter was reported to form a stronger bond between the soil particles.

Hamdan and Kanazanjian introduced a urea hydrolysis-based enzyme-induced carbonate precipitation (EICP) technique to stabilize fugitive dust [48]. Urease enzyme (urea amidohydrolase) that is found in different plants and microbes is used as a catalyst in this process. Firstly, urea $\left(\mathrm{NH}_{2}-\mathrm{CO}-\mathrm{NH}_{2}\right)$ is hydrolyzed in the presence of urease enzyme to form ammonium ion and carbon dioxide. Later, the ammonium ion reacts with the bivalent ions of the soil, such as $\mathrm{Ca}^{2+}$ and $\mathrm{Mg}^{2+}$, under suitable geochemical conditions and forms carbonate. Three different types of soils were chosen for tests: Ottawa F-60 silica sand, Arizona silty fine sand, and mine tailings. The soils were treated with the EICP solution that comprises calcium chloride, urea, and urease enzyme. To compare the performance, the authors applied the other three solutions on the soil samples: control sample (no treatment), water control (mixed with water before the study), and salt control (sand mixed with calcium chloride and urea). The odor of ammonia was found after 5-10 min of application of EICP solution on soils, which confirmed the efficacy of the urease enzyme to promote the hydrolysis of urea. However, no odor was found from the other samples. Wind test was performed on the sample by planetary wind tunnel to find the threshold detachment velocity (TDV), i.e., the velocity of air at which the soil particle becomes entrained into the air. The air velocity of the wind tunnel was increased gradually up to the tunnel's safe operating velocity of $25 \mathrm{~m} / \mathrm{s}$ until the start of the detachment of soil particles. It was found that for Ottawa F-60 silica sand and Arizona silty fine sand that the 1 and $2 \mathrm{M}$ (molar concentration) EICP-applied soil samples were able to perform the best withstanding $25 \mathrm{~m} / \mathrm{s}$ velocity of air. In the case of mine tailings, the samples with EICP solutions lower than $0.4 \mathrm{M}$ concentration showed entrainment below $25 \mathrm{~m} / \mathrm{s}$ wind velocity, wherein the $0.4 \mathrm{M} \mathrm{EICP}$-applied sample was the best performer, withstanding $25 \mathrm{~m} / \mathrm{s}$ wind velocity. Moreover, SEM images confirmed the presence of calcium carbonate in the soil.

The enzyme-based dust suppressants are environmentally friendly and ecologically compatible [46]. Nevertheless, being biodegradable, this class of suppressants needs to be applied frequently, like protein-based dust suppressants, which subsequently increases the maintenance cost of the unpaved roads [45]. However, urea freed from the EICP process can be detrimental to wildlife [47]. Furthermore, their initial production, preservation, and application procedure are more sophisticated, making them less viable for largescale applications.

\subsubsection{Biopolymers}

Biopolymers are mainly extracted from plants that stabilize dust particles by agglomeration. Corn starch and guar gum are the most popularly used biopolymers that have been discussed in the following section.

\section{Corn Starch}

Cornstarch is a low-cost and naturally available hydrophilic biopolymer material that has gained a large amount of attention in recent years [57]. It controls the emanation of fugitive dust by restraining the evaporation of water molecules. Retainment of water molecules ensures the binding of dust particles [49]. Lai et al. [51], Dang et al. [49], and Bao et al. [50] have explored the characteristics of cornstarch-based organic dust suppressants [51].

Lai et al. [51] synthesized the polymer dust suppressants (PDS) by combining acrylic acid (A.A.), acrylamide (AAM), and oxidized starch under microwave irradiation, which suppresses dust by using its agglomeration and hygroscopicity ability [51]. After obtaining the PDS-based dust suppressant, the PDS solution was applied to the coal samples to evaluate the efficacy of the PDS in suppressing the dust particles. PDS exhibited a stable dust suppression performance under the temperature ranging between $-12{ }^{\circ} \mathrm{C}$ and $50^{\circ} \mathrm{C}$. While the loss rate of the coal in the wind corrosion resistance test carried out at wind speed of about $4-15 \mathrm{~m} / \mathrm{s}$ for $3 \mathrm{~h}$ was found to be $1.2 \%$, the loss rate of distilled water was found to 
be $9.1 \%$ under the same condition. Moreover, a stable performance of the PDS solution was noticed during the soak test while subjecting it to a water-based corrosion. The test results strongly advocate the application of PDS suppressant in the areas with high precipitation as its agglomeration effect can be enhanced at increased moisture. Additionally, the SEM studies confirmed a strong bond formation between the PDS solution and the coal particles suppressing the coal dust.

Dang et al. [49] prepared a blend of oxidized corn starch (OCS) and gelatin (Gel)-based dust suppressant by mixing oxidized corn starch with degraded gelatin, hydrochloric acid, hydrogen peroxide, sodium hydroxide, and sodium carboxymethyl cellulose [49]. The effectiveness of this developed OCS-Gel-based dust suppressant was studied by performing lab experiments. About $68 \%$ and $79 \%$ of $\mathrm{PM}_{2.5}$ and $\mathrm{PM}_{10}$ fugitive dust particle suppressions, respectively, were observed with the application of OCS-Gel-based dust suppressants. The SEM characterization of Gel and OCS-Gel demonstrated a clear difference between their water retention capacities. The formation of a thin film on the dust surface by the OCS-Gel combination was observed, which prevented the evaporation of water keeping dust particles agglomerated. Moreover, the results from thermogravimetric studies indicated that the OCS-Gel has exceptional thermal stability, and this dust suppressant can be applied successfully in acidic, alkaline, or salty environments. Moreover, with only a $2 \%$ concentration of OCS-Gel, the hygroscopic degree, i.e., the gain of water by a hygroscopic substance per unit area per time, was found to reach $85 \%$. These characteristics make OCS-Gel-based products a suitable candidate for dust suppression. Unlike the PDS developed by Lai et al. [51], OCS-Gel composite dust suppressant is applicable in every environmental condition, owing to its superior water retention capacity when compared to PDS.

In continuation of Lai et al. [51], Bao et al. [50] experimented on co-polymerized cornstarch. A starch-grafted copolymer with acrylic acid and acrylamide was synthesized, wherein the acrylic acid was 50\% neutralized by sodium hydroxide [50]. The starch-based dust suppressants tightly agglomerate the dust particles by filling up the space between the dust particles. Further, the thermogravimetric test results proved the thermal stability of the dust suppressants. Despite the co-polymerization of the cornstarch, Bao et al. [50] achieved a fair amount of anti-evaporation rate and agglomeration effect on the dust particles, similar to Dang et al. [49].

Cornstarch-based dust suppressants are environmentally friendly and biodegradable [50]. Notably, in contrast to the efficacy of OCS-Gel composite dust suppressant in reducing the emission of $\mathrm{PM}_{2.5}$ and $\mathrm{PM}_{10}$, the dust suppressant prepared by Lai et al. [51] and Bao et al. [50] were efficient for coal dust. However, further research is still needed to be carried out to develop a better understanding of the decomposition period of corn starch and the required frequencies of application per year to achieve ideal dust suppression.

\section{Guar Gum (G.G.)}

Guar gum (G.G.) is a natural polymer derived from guar beans and is commercially available at a low price [52]. The potential of the G.G. as a soil stabilizer and a metal chelating agent was previously demonstrated by Kim et al. [58]. Motivated by the performance of G.G. in soil stabilization, Chen et al. [52] and Zhang et al. [53] investigated the role of G.G. as a dust suppressant. G.G. was observed to interact with the dust particles and form a coating around them, which in turn facilitates agglomeration of dust particles. The cementing ability of G.G. was attributed to its chemical structure comprising D-mannose straight chain with $\alpha-(1,4)$ bonds, wherein every two mannoses are attached to a D-galactose [53].

In the study carried out by Chen et al. [52], G.G. was compared to another dust suppressant, namely, xanthan gum. Both dust suppressants were prepared by mixing them with the tap water. The mixture was then continuously stirred with a hand mixer until a homogeneous solution was obtained. The effectiveness of different weight concentrations of G.G. solution was investigated by applying them on the mill tailing or mine tailing (M.T.) samples at a rate of $1.9 \mathrm{~L} / \mathrm{m}^{2}$. Two tests were carried out, namely, moisture retention 
test and wind tunnel test. On the basis of the moisture retention test results, the authors concluded that the $1.6 \%$ concentration of G.G. and xanthan gum had excellent moisture retention capacity even after five wet-dry cycles. Furthermore, the wind tunnel tests suggested that a 1.6\% concentration of G.G. and xanthan gum resulted in a reduced weight loss of the M.T.s. Further, the surface morphology characterization studies of biopolymer stabilized M.T.s through SEM analysis revealed the formation of a denser structure where the voids were filled by biopolymer, thereby coating and binding the M.T. particles.

Unlike the studies carried out by Chen et al. [2], which included unmodified guargum, the studies carried out by Zhang et al. [53] included a modified guar gum. The modification was made to improve the viscosity of the G.G.-based dust suppressant. For this purpose, Zhang et al. [53] used sodium sulfamate-modifying cyanuric chloride (TCS) substance to alter the hydroxyl (-OH) hydrophilic group in G.G. to produce modified guar gum (GGTCS)-based dust suppressant. The morphological analysis of the solidified film on the coal powder surface exhibited the agglomeration and solidification effects of the coal dust samples treated with GGTCS, which was able to suppress the diffusion of the coal dust sample. The water retention test revealed a lower evaporation rate for GGTCS concentrations within the range of $0.5-0.8 \%$. However, the role of guar gum modification to improve the overall viscosity was not clear from their experiment. Although Chen et al. [52] developed the dust suppressant from guar gum as raw material, it had a similar dust suppressant ability as GGTCS developed by Zhang et al. [53].

G.G.-derived dust suppression materials possess several advantages, such as biodegradability, cost-effectiveness, and eco-friendliness. However, there is a necessity for further studies to be conducted on the long-term performance of guar gum-based dust suppressants after application.

\subsubsection{Chitosan}

Chitosan (CTS) is derived from chitin, which includes the exoskeleton of chitin and fungi [57]. It is an inexpensive degradable biopolymer [59]. CTS-based dust suppressants agglomerate the dust particles and form a layer over dust particles that acts as a shield against wind erosion [54]. Liu et al. [54] modified raw chitosan material to obtain a quaternary ammonium salt (i.e., N-(2-hydroxyl) propyl-3-trimethyl ammonium chitosan chloride (HTCC)) that can be used as a dust controller. Fourier transform infrared (FTIR) spectrograph of a chitosan-based dust suppressant revealed that the hydrogen atom of the nucleophilic center, $-\mathrm{NH}_{2}$, is replaced by $-\mathrm{CH}_{2} \mathrm{CH}(\mathrm{O} . \mathrm{H}$. $) \mathrm{CH}_{2} \mathrm{~N}^{+}\left(\mathrm{CH}_{3}\right) \mathrm{Cl}^{-}$. On the other hand, the comparison of SEM characterization between the dry coal powder particles and the dust suppressant applied coal powder particles revealed an appreciable level of agglomeration and solidification for the latter sample where the HTCC-based dust suppressant was applied. Moreover, in the SEM images of coal dust samples treated with HTCC, a bonding layer was found to be formed on the coal dust surface that can significantly contribute to wind erosion prevention and water retention. However, the desired viscosity of the dust suppressant was achieved for $0.025 \%(\mathrm{w} / \mathrm{w})$ concentration of modified HTCC, and this concentration was chosen for further evaluation as a dust controller. Moreover, coal samples with HTCC exhibited good endurance until the wind velocity becomes equivalent to force- 8 wind, i.e., a wind of velocity $17 \mathrm{~m} / \mathrm{s}$, and at that point, only $14.37 \%$ of the initial mass of the coal dust was lost as found from the wind erosion resistance test.

Raab et al. [55] formulated and patented a process of obtaining a poly (METAS)-chitosanbased polymer dust suppressant from chitosan and 2-methacryloyloxyethyltrimethyl ammonium methyl sulfate [55]. The inventors claimed that this dust suppressant would be able to bind the friable soil particles together into bigger particles, preventing dust from becoming airborne. However, despite the degradability and non-toxicity of CTS similar to cornstarch and guar gum [55], poor water solubility leaves scope for further modification of the chitosan to achieve excellent dust suppression results [54]. 


\subsubsection{Liquid Polymers}

Lee et al. [56] studied the effect of a liquid polymer-based organic dust controller on $\mathrm{PM}_{2.5^{-}}$and $\mathrm{PM}_{10^{-}}$-sized particles. To prepare a liquid polymer solution, the authors mixed the liquid amphiphilic poly triblock copolymer (PEO-PPO-PEO) with the liquid hydrophilic polyethylene glycol (PEG) in the deionized (DI) water. When a liquid polymer is used as an additive in water, it will maintain moisture on the dust sources, decreasing the emission of fine particles into the air [56]. Results from the lab-based air blown test revealed that $7 \%(\mathrm{v} / \mathrm{v})$ of PEG solution reduced the $\mathrm{PM}_{10}$ by $87 \%$ and $\mathrm{PM}_{2.5}$ by $86 \%$ compared to the sample where water was applied to suppress dust. On the contrary, $3 \%(\mathrm{v} / \mathrm{v})$ of the PEO-PPO-PEO solution reduced $\mathrm{PM}_{10}$ by $91 \%$ and $\mathrm{PM}_{2.5}$ by $89 \%$. However, until $5 \%(\mathrm{v} / \mathrm{v})$ concentration of PEO-PPO-PEO, the increment of concentration decreased the concentration of $\mathrm{PM}_{2.5}$ and $\mathrm{PM}_{10}$ and then the dust concentrations started to increase if the concentration of PEO-PPO-PEO is further increased. This indicates that the optimum concentration of PEO-PPO-PEO is between 3-5\% (v/v). Further, pilot test results indicate that with liquid PEO-PPO-PEO aqueous solution, $\mathrm{PM}_{10}$ and $\mathrm{PM}_{2.5}$ reduced by $86 \%$ and $92 \%$, respectively, whereas PEG aqueous solution reduced the $\mathrm{PM}_{10}$ by $53 \%$ and $\mathrm{PM}_{2.5}$ by $58 \%$.

The liquid polymers were selected because of their biocompatibility, easy adaptability, and eco-friendliness [56]. However, there is a risk of secondhand pollution due to the decomposition of PEO-PPO-PEO and PEG.

\subsection{Hybrid Dust Suppressants Using Bio-polymers Combined with Chemical Agents}

Biopolymers can be combined with different chemical agents to obtain hybrid dust suppressants. The list of hybrid dust suppressants synthesized by various researchers in the past is summarized in Table 2, and a brief discussion on each dust suppressant is provided in this section. 
Table 2. Review of biopolymer combined with chemical agent dust suppressants used for suppressing dust.

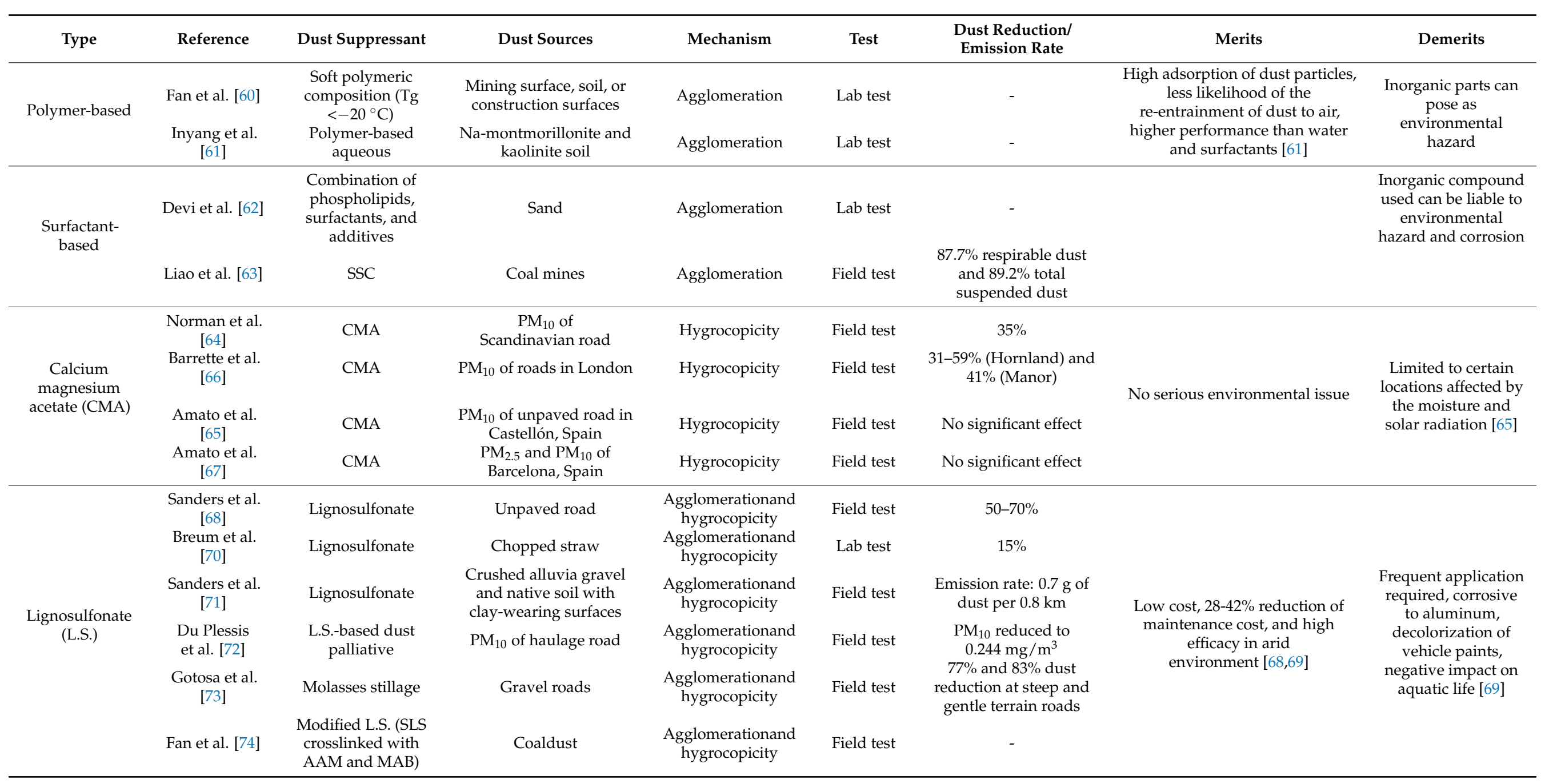




\subsubsection{Polymer-Based Aqueous Dust Suppressant}

Fan et al. formulated and patented a soft coating polymer-based dust suppressant [60]. The formulation of coating polymer is mainly comprised of water-based polymers such as polyacrylate (e.g., an acrylic emulsion polymer), synthetic rubber and natural rubber, polyurethane, and silicone polymers that are able to agglomerate dust particles. Unlike other polymer-based dust suppressants such as polyvinyl acetate and vinyl acrylic polymer latex, which possessed glass transition temperatures $\left(\mathrm{T}_{\mathrm{g}}\right)$ greater than $0{ }^{\circ} \mathrm{C}$ and were adequate to sustain only static conditions of traffic, the authors aimed at developing a dust suppressant that has low glass transition temperature that can sustain under dynamic conditions such as moving and tumbling of heavy traffic. Both static and dynamic dust control tests demonstrated a correlation between the $T_{g}$ of the polymer and its dust suppression performances. Lower $\mathrm{T}_{\mathrm{g}}$ polymers exhibited increased dust suppressant performance.

Inyang et al. [61] investigated the performances of three different polymer-based aqueous dust suppressants, namely, sodium carboxymethyl cellulose (CMC A), polyacrylamide (PAM B), and polyethylene oxide (PEO A), on sodium montmorillonite (Namontmorillonite) and kaolinite (K) soil samples. Specifically, the authors carried out the desiccation tests in an environmental chamber that was maintained at $25^{\circ} \mathrm{C}$, and relative humidity of $30 \%$, wherein the weight loss of dust suppressant-treated soil samples was measured at regular time intervals. In their study, each dust suppressant was mixed with distilled water to form a solution of different concentrations. In addition to the desiccation tests, the authors also performed a cost analysis study to determine the optimal concentrations of dust suppressants for both soil samples. While desiccation tests revealed that $\mathrm{CMC}$ at concentrations ranging from 4 to $6 \mathrm{~g} / \mathrm{L}(\mathrm{w} / \mathrm{v})$ would be optimal for both Na-montmorillonite and kaolinite samples, cost analysis studies revealed that PAM with concentration below $1 \mathrm{~g} / \mathrm{L}(\mathrm{w} / \mathrm{v})$ and PAM with concentration up to $2 \mathrm{~g} / \mathrm{L}(\mathrm{w} / \mathrm{v})$ are optimal for Na-montmorillonite and kaolinite, respectively. SEM images showed myriad pores in the cross-linked product, which created an agglomeration effect to capture coal dust particles and stabilize them.

The hybrid dust suppressants have more advantages over water- and surfactant-based suppressants. Moreover, they exhibit appreciable adsorption to dust particles, reducing the likelihood of the re-entrainment of dust into the air [61]. However, the inorganic compounds used here can be a threat to the environment.

\subsubsection{Surfactant-Based Dust Suppressants}

Devi et al. [62] introduced a patented process to form biodegradable aqueous-based dust suppressants from phospholipids, surfactants, and additives. The additives were selected from polyhydric alcohol, urea, monosaccharide, polysaccharides, polyacrylic acid, polyethylene glycol, polysiloxane, lignosulfonate, and macrocrystalline wax. However, no performance metrics were provided for this patented biodegradable aqueous-based dust suppressant. Liao et al. [63] developed a dust suppressant that consisted of surfactants and celluloses (termed combinedly as SSC), wherein several inorganic salts, i.e., sodium chloride $(\mathrm{NaCl})$, calcium chloride $\left(\mathrm{CaCl}_{2}\right)$, sodium sulfate $\left(\mathrm{NaSO}_{4}\right)$, and hydrated magnesium chloride $\left(\mathrm{MgCl}_{2} \bullet 6 \mathrm{H}_{2} \mathrm{O}\right)$, were used as synergists to create a better dust suppression effect. They are hygroscopic by nature. Hence, they can create moisture tension between the fine particles [75]. The optimal material combination for SSC was determined on the basis of the standard sedimentation experiments and viscosity tests. Moreover, the efficiency of the dust suppression of the respirable and the total dust concentration in coal mine roadway by the SSC-applied sample was found to be $65.6 \%$ and $44.5 \%$ more, respectively, than the cases where the conventional water curtain method was used, involving a curtain of water to suppress dust.

As SSC contains celluloses that are biodegradable, this portion of SSC is environmentally friendly and does not cause any secondary pollution [59]. However, synergist ions used in this kind of dust suppressant, such as $\mathrm{NaCl}, \mathrm{CaCl}_{2}, \mathrm{NaSO}_{4}$, and $\mathrm{MgCl}_{2} \bullet 6 \mathrm{H}_{2} \mathrm{O}$, are harmful to certain plant species and toxic to the environment [69]. 


\subsubsection{Calcium Magnesium Acetate (CMA)}

Calcium magnesium acetate (CMA) is popularly used as a deicer. However, the use of CMA to stabilize fugitive dust particles has been suggested by the literature. This type of dust suppressant can form hygroscopic coating on a road surface that keeps it moist and thus the dust can be barred to be entrained in the air. Norman and Johansson demonstrated CMA-based dust suppression method to reduce $\mathrm{PM}_{10}$ in the Scandinavian region [64]. They formulated a solution of CMA and sprayed it on roads. They conducted the test for 21 days and observed an average reduction of $35 \%$ of the initial $\mathrm{PM}_{10}$ concentration. However, the level of reduction varied on the basis of the different time of day, relative humidity, wind velocity, and load of traffic on the road. From a similar study, Barrette et al. were able to reduce road dust emission by $31-59 \%$ and $41 \%$ from Hornland and Manor roads in London, respectively, by applying CMA daily [66]. However, the efficacy of the dust suppression is strongly dependent on the pavement types, solar radiation and moisture of a location, and the dustiness of a road [65]. They conducted their experiments in the southern part of Europe where road dust and emission strength are higher [76]. Amato et al. assessed the effect of CMA on unpaved industrial roads within a quarry at Castellón (Spain) [65]. Three types of tests were performed on roads: (a) water spray, (b) CMA mixed water spray, and (c) CMA spray on watered road. They found street washing by water spray was the most effective way of suppressing dust particles, which can reduce more than $90 \%$ of initial $\mathrm{PM}_{10}$ level up to the first hour where no significant change in $\mathrm{PM}_{10}$ level was observed for CMA-applied roads. A similar result was found in another study conducted by Amato et al. in Barcelona city, wherein the effect of CMA was found insignificant in $\mathrm{PM}_{10}$ and $\mathrm{PM}_{2.5}$ reduction [67].

Although CMA can be a good solution to address fugitive dust problem in some sites with no serious environmental issue, frequent application is required. Moreover, the performance of CMA is greatly affected by the relative humidity and solar radiation.

\subsubsection{Ligno-Sulfonate Dust Suppressant}

L.S. is an organic compound-based dust suppressant derived as a byproduct of the sulfite pulping process of the plant material. Plant material mainly comprises lignin, which is a natural polymer and acts as a cementing agent. Lignin has a molecular chain structure with three repeated phenylpropane units (monolignols), namely, p-coumaryl alcohol, coniferyl alcohol, and sinapyl alcohol [70,77]. The monolignols undergo a biosynthesis reaction involving dehydrogenative polymerization reaction forming macromolecular lignin by random coupling. During the sulfite pulping process of wood, the breakage of bonds occurs between the lignin and polysaccharides. Consequently, this phenomenon results in the reduction of the molecular weight of the total lignin structure, which transforms into a water-soluble form [77]. During this process, lignin polymers and wood sugars are released into the sulfite processing wastewater, which is referred to as L.S. [75]. L.S. can induce the retardation in water evaporation owing to its hygroscopic properties and can form agglomerates by cementing the soil or dust particles. Both these aspects of L.S. can combinedly help in suppressing the fugitive dust from the unpaved roads.

L.S. has been used in the past as a stand-alone dust suppressant in diluted form or mixed with other materials to suppress the dust. The dust-suppressing capability of L.S. was first demonstrated by Sanders et al. [68] through an initial field test on unpaved roads. The field test data indicated a reduction in the emission of the dust from the unpaved road ranging between 50 and $70 \%$ after applying L.S. at a rate of $2.3 \mathrm{~L} / \mathrm{m}^{2}$. In another study, Breum et al. [70] investigated the effect of the L.S. as a dust controller on the dustiness of the chopped straw. A mechanical dust separator was coupled with different concentrations of L.S., and the quality of dust suppression was assessed. On the basis of the experimental results, the researchers concluded that the $27 \%$ concentration of L.S. solution with an active dust separator can reduce $15 \%$ of the airborne dust. Nevertheless, any further increment in the concentration of the L.S. solution was not found to have any improvement in dust suppression. The efficacy of L.S. on the crushed alluvia gravel and native soil with clay- 
wearing surfaces was assessed by Sanders et al. [71]. On the basis of the field test results, the authors concluded that the L.S.-treated surface generated $0.7 \mathrm{~g}$ of dust per $0.8 \mathrm{~km}$ on an average.

Du Plessis et al. formulated and studied an L.S.-based dust palliative on a haulage road and compared the result with water-applied road [72]. They found a drastic change in $\mathrm{PM}_{10}$ after the application of the L.S.-based dust palliative, and the concentration of $\mathrm{PM}_{10}$ was found as $0.244 \mathrm{mg} / \mathrm{m}^{3}$, which is $47.3 \%$ less that of water-applied roads. Moreover, the researchers evaluated the financial impact of their dust suppressant. In total, 30\% more savings is possible in the cost of maintenance, operation, and fuel if L.S.-based dust palliative suppressant is chosen instead of water. Gotosa et al. developed an L.S.-based dust suppressant from molasses stillage that contained magnesium L.S., sugar, humic acid, and fulvic acid, which was applied on steep and gentle terrain roads [73]. Similar to L.S., it can also create an agglomeration effect in soil by binding the particles by physical and chemical interaction. Moreover, the sugar part of this suppressant can show hygroscopicity in the humid zones. They authors have experienced $77 \%$ and $83 \%$ reduction of the accumulation of settleable road dust in steep and gentle terrain roads, respectively, by applying this dust suppressant.

Although the L.S. dust suppressants exhibited promising results, as reported by Sanders et al. [68] and Breum et al. [70], one of the major limitations is that the binding capability of L.S. has been noticed to reduce significantly by heavy rain. This has been attributed to the water solubility of L.S. [75]. To overcome the challenge of water solubility, Fan et al. [74] synthesized a modified L.S. dust suppressant by crosslinking sodium-lignosulfonate (SLS) with acrylamide (AAM) and methylene diacrylamide (MAB). For assessing the effectiveness of the synthesized dust suppressant, the authors carried out a single-factor experiment on the coal dust [74], i.e., the mass was manipulated every time in the experiments with varying amounts of SLS, AAM, MAB, to AAM ratios, and temperature ranges. The subsequent scanning electron microscope-based characterization of agglomerates confirmed agglomeration effects on the coal particles with the crosslinked product with strong adsorption to the dust. The thermal stability of the product under the TG-DSC (glass transition-differential scanning calorimetry) experiment was also additionally characterized.

While the advantages of the L.S. includes low-cost and relatively high effectiveness in treating dust under dry conditions, the limitations include the necessity for frequent application, being corrosive to aluminum, its decolorization of vehicle paints, and its negative impact on aquatic life, which leaves ample scope for further investigations [69].

\subsection{Inorganic Dust Suppressants}

Inorganic compound-based dust suppressants are derived from inorganic compounds, i.e., sources that are not directly associated with living bodies, microbes, or plants. Almost $75-80 \%$ of the dust control materials are derived from inorganic sources [78]. This class of dust suppressants covers a wide gamut of materials, including chloride salts, silicates, and surfactants. In this section, different inorganic dust suppressants and studies on their performance to control fugitive dust are reviewed (see Table 3). 
Table 3. Review of inorganic dust suppressants used for suppressing dust.

\begin{tabular}{|c|c|c|c|c|c|c|c|c|}
\hline Type & Reference & $\begin{array}{l}\text { Name of Dust } \\
\text { Suppressants }\end{array}$ & Dust Sources & Mechanism & Test & $\begin{array}{l}\text { Dust Reduction/ } \\
\text { Emission Rate }\end{array}$ & Merits & Demerits \\
\hline \multirow{2}{*}{ Chlorides } & Sanders et al. [68] & $\mathrm{MgCl}_{2}$ and $\mathrm{CaCl}_{2}$ & Unpaved road & Hygroscopicity & Field test & $50-70 \%$ & \multirow[t]{2}{*}{$\begin{array}{l}\text { Less toxic and costly, high } \\
\text { dust suppression }\end{array}$} & \multirow{2}{*}{$\begin{array}{c}\text { Negative impact on } \\
\text { aquatic life, concrete, and } \\
\text { steel infrastructure }[79,80], \\
\text { frequent applications } \\
\text { required [69] }\end{array}$} \\
\hline & Edvardsson [81] & $\mathrm{MgCl}_{2}$ and $\mathrm{CaCl}_{2}$ & $\mathrm{PM}_{10}$ & Hygroscopicity & Field test & $\begin{array}{c}0.6 \mathrm{mg} / \mathrm{m}^{3}\left(\mathrm{MgCl}_{2}\right) \\
\text { and } 0.2 \mathrm{mg} / \mathrm{m}^{3}\left(\mathrm{CaCl}_{2}\right)\end{array}$ & & \\
\hline \multirow{2}{*}{$\begin{array}{l}\text { Byproducts } \\
\text { and waste } \\
\text { products }\end{array}$} & Cotter et al. [82] & Expired beverages & $\begin{array}{l}\text { Construction } \\
\text { site }\end{array}$ & Agglomeration & - & - & \multirow{2}{*}{$\begin{array}{l}\text { Low cost and scopes of } \\
\text { recycling of wastes }\end{array}$} & \multirow{2}{*}{ Risk of pollution [83] } \\
\hline & $\begin{array}{c}\text { Dixon-Hardy et al. } \\
{[83]}\end{array}$ & $\begin{array}{l}\text { Petroleum refinery } \\
\text { waste }\end{array}$ & Coal mine & Agglomeration & Lab test & $1.5 \mathrm{mg} / \mathrm{m}^{3}$ & & \\
\hline \multirow{3}{*}{$\begin{array}{l}\text { Inorganic } \\
\text { oil-chemical } \\
\text { combination }\end{array}$} & Hey et al. [84] & $\begin{array}{c}\text { Synthetic } \\
\text { triglycerides }\end{array}$ & $\begin{array}{c}\text { Mineral } \\
\text { substrates }\end{array}$ & Agglomeration & - & - & \multirow{3}{*}{$\begin{array}{l}\text { High efficiency and less } \\
\text { requirement of } \\
\text { application }\end{array}$} & \multirow{3}{*}{$\begin{array}{l}\text { Costly, noxious effect of } \\
\text { oil impurities on nature }\end{array}$} \\
\hline & $\begin{array}{l}\text { Medeiros et al. } \\
{[85]}\end{array}$ & Glycerol & Iron ore & Agglomeration & Lab test & $92 \%$ & & \\
\hline & Gillies et al. [86] & $\begin{array}{l}\text { PE, PEP, and } \\
\text { NHCO }\end{array}$ & $\begin{array}{l}\text { Unpaved } \\
\text { roads }\end{array}$ & Agglomeration & Field test & $\begin{array}{c}83 \%(\mathrm{PE}), 44 \%(\mathrm{PEP}), \\
\text { and } 95 \%(\mathrm{NHCO}) \\
\text { efficiency }\end{array}$ & & \\
\hline $\begin{array}{l}\text { Magnetized } \\
\text { surfactants }\end{array}$ & Ding et al. [87] & Surfactant & Coal mine & Agglomeration & Lab test & - & $\begin{array}{l}\text { Economical, readily } \\
\text { available, and } \\
\text { water-soluble [87] }\end{array}$ & Limited to coal mine dust \\
\hline \multirow{2}{*}{$\begin{array}{l}\text { Aqueous- } \\
\text { based }\end{array}$} & Xi et al. [88] & Foam-sol & Coal mine & Agglomeration & Lab test & $2 \mathrm{mg} / \mathrm{L}$ & $\begin{array}{l}\text { Foam-sol-based products' } \\
\text { being able to penetrate }\end{array}$ & \multirow{2}{*}{$\begin{array}{l}\text { Limited feasibility and } \\
\text { harmful impact on human } \\
\text { health and environment }\end{array}$} \\
\hline & O’ Brien et al. [89] & Aqueous & - & Agglomeration & - & - & $\begin{array}{l}\text { dust particles' crack and } \\
\text { fill voids in them [88] }\end{array}$ & \\
\hline
\end{tabular}




\subsubsection{Chlorides}

The potential of various chloride-based salts, e.g., sodium chloride $(\mathrm{NaCl})$, magnesium chloride $\left(\mathrm{MgCl}_{2}\right)$, and calcium chloride $\left(\mathrm{CaCl}_{2}\right)$, as dust suppressants were investigated by various researchers in the past [78]. All the chloride-based salts share a common working principle for suppressing the dust, i.e., they draw the moisture from the atmosphere onto the aggregate surface due to their inherent hygroscopic nature and hence bind the particles together [75].

Initially, Sanders et al. [68] experimented with the efficacy of chloride-based dust suppressants on the unpaved road sections. Application of calcium chloride $\left(\mathrm{CaCl}_{2}\right)$ and magnesium chloride $\left(\mathrm{MgCl}_{2}\right)$ indicated a reduction of dust emission by $50-70 \%$ at an application rate of $0.5 \mathrm{gals} / \mathrm{yd}^{3}$ [68]. Goodrich et al. [90] studied the performance of $\mathrm{MgCl}_{2}$ dust suppressant on the surface water chemistry next to the treated unpaved road in Colorado, USA. The water samples for chemical analyses were obtained from the selected upstream and downstream sample sites. The study revealed that the $\mathrm{MgCl}_{2}$ ions did not affect the surface water characteristics significantly. However, magnesium and chloride ions from $\mathrm{MgCl}_{2}$ are leached through water streams. The seeping of magnesium and chloride ions from the chloride-based dust suppressants into surface water bodies limits the application of chloride-based dust suppressants.

Another study by Sanders et al. [71] examined the efficacy of magnesium chloride $\left(\mathrm{MgCl}_{2}\right)$ and a proprietary blend of $\mathrm{MgCl}_{2}$ and lignin on the crushed alluvia gravel and native soil with clay-wearing surfaces. On the basis of the field test performed, the authors concluded the surface treated with $\mathrm{MgCl}_{2}$ generated an average of $0.4 \mathrm{~g}$ of dust per $0.8 \mathrm{~km}$. Both of their studies performed in 1997 and 2014 showed a successful suppression of the dust emission when chloride-based suppressants were used [68,71]. Edvardsson found the application rate as an important parameter that influences the dust control where the higher application rate shows more dust control [81]. They found crystalized calcium chloride of equivalent weight-basis chloride showed higher efficiency in dust suppression than crystallized magnesium chloride.

In a nutshell, chloride-based dust suppressants are very useful in suppressing dust because they are less toxic and costly. Nevertheless, the adverse impact on aquatic flora and fauna, concrete, and steel infrastructure [78,79], as well as the need for frequent applications are some of the issues to be considered before using chloride-based dust suppressants [69].

\subsubsection{Byproducts and Waste Products as Dust Suppressants}

The byproducts obtained from the beverage processing industries and petroleum refineries are explored as dust suppressant alternatives in the literature. For instance, Cotter et al. [82] demonstrated the role of expired beverages (e.g., soft drinks and juices) as dust suppressants by applying them on the premises of construction sites [82]. The method of application involves filling a water truck with a mixture of expired beverages and applying this mixture on the construction sites. However, no dust suppression performance metrics were specified in this patent.

In another study by Dixon-Hardy et al. [83], petroleum refinery waste, such as sulphidic and phenolic waste, was investigated, which exhibited higher adhesion forces, resulting in the formation of bonding layers on the dust particles, thus agglomerating them into a larger size $[82,83]$. This feature of the refinery waste inspired Dixon-Hardy et al. [83] to assess its performance as an ideal choice for suppressing coal dust. Further, the influence of different concentrations of sulphidic and phenolic wastes was assessed on the dust particles inside a dust chamber. On the basis of the experimental data, the authors concluded that a $2.0 \%(\mathrm{w} / \mathrm{v})$ concentration of phenolic waste with a $60-\mathrm{s}$ spraying time could generate the best result at $12 \mathrm{~min}$ with the least amount of dust concentration in the air. However, the refinery waste can be noxious to the environment as well as the health of mineworkers. Further studies are needed to explore the applications of this method of dust suppression [83]. 


\subsubsection{Inorganic Oil Chemical Combination-Based Dust Suppressants}

Hey et al. [84] employed triglycerides as a dust-suppressing agent in their patented process. Triglycerides are the esters of glycerin and natural oils, e.g., soybean oil, sunflower oil, paraffin oil, coconut oil, palmitic oil, cottonseed oil, and castor oil. However, this type of dust suppressant falls into the category of inorganic compound-based dust suppressant as the formulation of a triglyceride requires the combination of soyabean oil and inorganic HCF-740, i.e., a stable foam creating a mixture of fluorosurfactants and hydrocarbon solvent [84]. Later, Medeiros et al. [85] evaluated the performance of glycerol-based nonorganic dust suppressant. Glycerol is a co-product of biodiesel fuel and is viscous and hygroscopic. When glycerol is applied to soil particles, it creates a thin layer, blocking the wind from breaking through the soil particles. Glycerol was oligomerized with $\mathrm{H}_{3} \mathrm{PO}_{4}$ or of $\mathrm{NaOH}, \mathrm{H}_{2} \mathrm{SO}_{4}$, and distilled water to derive this product. Wind tunnel tests revealed that the products of $0.5 \%$ and $0.125 \%$ mass basis concentration combined with $2 \mathrm{~mol} \%$ $\mathrm{H}_{2} \mathrm{SO}_{4}$ were found as the most efficient and better than a commercial product as claimed in the original manuscript. Viscosity test revealed that the glycerol with increasing catalyst concentration produces a higher viscosity and can reach more than 160 times of that of glycerol [85]. On the other hand, Gillies et al. studied the performance of polymer emulsion (PE), petroleumemulsion with polymer (PEP), and nonhazardous crude oil (NHCO)-containing material-based commercial products, applying them on unpaved roads, which stabilized fugitive dust particles by agglomeration [86]. After a year of study, the outcome of the experiment found the average efficiency of dust suppression of PE, PEP, and NHCO to be $83 \%, 44 \%$, and $95 \%$, respectively. Longevity and high efficiency are the prime advantages of using these kinds of dust suppressants. However, high cost of the suppressants can be an obstacle to use them and impurities in the oils can affect the environment adversely.

\subsubsection{Magnetized Surfactants as Dust Suppressants}

Magnetized surfactants are hydrophilic substances with magnetic properties that possess the ability to attract water molecules, which can be organic or non-organic. As a consequence, they dampen the dust particles and bind them together to form agglomerates [87]. Ding et al. [87] examined the efficacy of magnetized surfactant solutions on the basis of a non-organic material for coal dust controllers. Four different non-organic surfactants were investigated in their study, namely, sodium dodecane sulfonate (SDS), sodium dodecyl benzenesulfonate, sodium dodecyl sulfate, and Triton. Among the four surfactants, Triton solution was found to outperform other surfactants owing to its ability to decrease surface tension quickly as the concentration increases. It was diluted into the water at different concentrations, and the solutions were magnetized using TYU- $2000 \mathrm{H}$ equipment. Contact angle experiments concluded that the Triton solution with a concentration of $0.02-0.03 \%(\mathrm{w} / \mathrm{v})$ yielded the best results. Moreover, a $\mathrm{pH}$ test showed that magnetized Triton has neutral $\mathrm{pH}$ values, making it appropriate for capturing coal mine dust. In general, this kind of surfactant is advantageous for being economical, readily available, and water-soluble [87].

\subsubsection{Aqueous-Based Dust Suppressants}

Foam-sol is a type of emulsion that can be created by grease, acetate, and a byproduct of a slow cross-linking reaction where a crosslinking agent and a surfactant water-based foam solution are used [88]. Foam-sol possesses high viscosity and cohesion, which in turn facilitates binding the fugitive dust particles, whose performance as suppressant was investigated. The wettability experiment showed that the foam-sol could permeate through the soil particles and adhere to the surface, binding the soil particles into larger particles. $\mathrm{X} i$ et al. developed a foam-sol-generating system and found foam-sol, with the volume and mass ratios of $37.1 \%$ and $30.54 \%$, respectively, to have higher cohesion and viscosities, thereby incorporating the capability to capture airborne dust [88]. It was concluded from 
the study that foam-sol and aqueous dispersion methods could reduce the generation of soil particles in the air.

O'Brien et al. [89] patented a technique to form a dust suppressant by mixing the aqueous dispersion stream. One of the methods to develop an aqueous dispersion stream is the transportation of surfactant compositions on the aqueous liquid stream using sufficient pressure to cover the surface. The stream creates surface tension in the dust particles and thus agglomerates them. The surface tension of the dust suppressant is measured by using a tensiometer. On the basis of the surface tension measurements, the authors adjusted the formation of the aqueous dispersion stream to maximize its effect.

Foam-sol developed by $\mathrm{Xi}$ et al. has the advantage of being able to penetrate the dust particles' crack and fill the voids in them, enhancing the action of the foam-sol [88]. Nevertheless, further investigation should assess the feasibility and the impact of foam-sol dust suppressants on the environment and human health.

\section{Findings, Limitations, and Recommendations}

\subsection{Findings from the Literature Review}

This paper systematically reviewed the dust suppressants belonging to three broad categories: organic compound-based, a combination of biopolymer and chemical, and inorganic compound-based dust suppressants. Additionally, the general mechanisms involved in suppressing the dust is also discussed. The following are the important findings in terms of the literature review:

- Most of the dust suppressants capture the dust particles either through their hygroscopic nature or agglomeration ability. Some dust suppressants exhibit a combination of both mechanisms to suppress dust. Hygroscopic dust suppressants adsorb/absorb moisture from the surrounding atmosphere and block the entrainment of dust into the air by wetting the dust particles. On the other hand, the agglomerative dust suppressants cement smaller dust particles to form a bigger mass by virtue of their adhesive nature and can also form a protective layer at the top surface that in some cases blocks dust particles from being entrained into the air.

- Organic dust suppressants are produced from the organic compounds extracted from flora and fauna. Protein-based, enzyme-based, biopolymer, chitosan, and liquid polymer dust suppressants are the most commonly used organic dust suppressants that generally use agglomeration ability to increase adhesion between the dust particles, cementing them into larger aggregates. Biodegradability, high availability, low flammability, and toxicity are some of the advantages of organic dust suppressants.

- The performance of biopolymers in dust suppression can be enhanced sharply by combining them with chemical agents. Where the bio-polymer part of the combination improves agglomeration, the addition of chemical agents, particularly hygroscopic chemical agents, can effectively improve the overall dust suppression quality by though hygroscopicity. The prime feature of this class of dust suppressants is their ability to retain an appreciable level of moisture content, high dust suppression rate, and reduction of maintenance cost. Moreover, the bio-polymer-chemical combination can be well sustained under heavy traffic.

- Inorganic compounds, e.g., chloride salts, byproducts, and waste products of industries; natural oil-inorganic compound combinations; magnetized surfactants; and foam-sol, can be used as dust suppressants as well. While the deliquescent chloride salts use their hygroscopicity for dust suppression, most of the other inorganic compounds improve the agglomeration among the dust particles to suppress dust. Water solubility, availability, high dust suppression, and excellent performance are the key features of inorganic dust suppression.

\subsection{Reccommendations}

On the basis of the literature review, we make the following recommendations for future research work. In addition to this, the limitations are also provided. 
- Organic compound-based dust suppressants can be used in rural highways, unpaved roads, agricultural roads, dirt roads, gravel roads, and mines without negatively impacting the local ecology. Low shelf-life, higher frequency of application, and leaching due to rainwater are some of the common limitations of organic dust suppressants. Hence, these issues should be considered while planning to use organic dust suppressants, and appropriate modification of these organic dust suppressants is necessary to address these limitations for broader applications.

- Bio-polymer-chemical combination of dust suppressants can have a toxic impact on nature due to the use of chemical agents in their synthesis. Certain organic dust suppressants such as lignosulfonate are harmful to aquatic life and are corrosive to aluminum. Therefore, the recommended sites for their application can be places such as coal mines and industries where employees use masks. Special treatments for the inorganic chemical agents used in the bio-polymer-chemical combination dust suppressants should be explored to decrease their negative impact on the environment.

- Similar to the bio-polymer-chemical combination, inorganic compound-based dust suppressants are not environment friendly. Leaching into the groundwater and altering the soil $\mathrm{pH}$ are the additional issues caused by inorganic compound-based dust suppressants. Modification of the inorganic compound-based dust suppressants should be investigated to minimize their harmful effects on the environment.

\subsection{Limitations}

The scope of the current paper is only limited to a brief overview of the aspects such as synthesis of the dust suppressants, their advantages and disadvantages, the working mechanism, and the environmental impacts. Details about the cost and ease of availability of dust suppressants were not included because of the insufficient and transient nature of the information in the literature. Further, the description of the environmental impacts of the dust suppressants falls outside the scope of this review.

Author Contributions: Conceptualization, R.K. and Y.H.; methodology, S.P., D.L.N., and H.U.S.; investigation, S.P.; resources, R.K.; writing-original draft preparation, S.P., N.T., D.L.N., and H.U.S.; writing-review and editing, R.K., Y.H., S.P., D.L.N., and H.U.S.; visualization, S.P. and D.L.N.; supervision, R.K.; project administration, R.K.; funding acquisition, R.K. All authors have read and agreed to the published version of the manuscript.

Funding: The authors gratefully acknowledge the financial support from the North Dakota Corn Utilization Council (FAR30704). Any opinions, findings, conclusions or recommendations provided in this paper are those of the authors and do not necessarily reflect the views of the funding agency.

Data Availability Statement: Not applicable.

Conflicts of Interest: The authors declare no conflict of interest.

\section{References}

1. Bureau of Transportation Statistics. National Transportation Statistics; Bureau of Transportation Statistics: Washington, DC, USA, 2018.

2. Addo, J.Q.; Sanders, T.G.; Chenard, M. Road dust suppression: Effect on maintenance stability, safety and the environment; Final Rep. MPC04; The National Academy of Sciences: Washington DC, USA, 2004.

3. Zhao, G.; Chen, Y.; Hopke, P.K.; Holsen, T.M.; Dhaniyala, S. Characteristics of traffic-induced fugitive dust from unpaved roads. Aerosol Sci. Technol. 2017, 51, 1324-1331. [CrossRef]

4. Michigan Department of Environmental Quality. Managing Fugitive Dust: A Guide for Compliance with the Air Regulatory Requirements for Particulate Matter Generation Managing Fugitive Dust; Michigan Department of Environmental Quality: Lansing, MI, USA, 2005.

5. Environmental Protection Agency (EPA). NEI Report Dashboard 2014; EPA: Washington, DC, USA, 2014. Available online: https:/ / edap.epa.gov/public/extensions/nei_report_2014/dashboard.html\#trend-db (accessed on 13 August 2020).

6. Bhattachan, A.; Okin, G.S.; Zhang, J.; Vimal, S.; Lettenmaier, D.P. Characterizing the role of wind and dust in traffic accidents in California. GeoHealth 2019, 3, 328-336. [CrossRef]

7. Greening, T. Quantifying the Impacts of Vehicle-Generated Dust: A Comprehensive Approach; World Bank: Washington, DC, USA, 2011. 
8. Bell, M.L.; Dominici, F.; Ebisu, K.; Zeger, S.L.; Samet, J.M. Spatial and temporal variation in PM 2.5 chemical composition in the United States for health effects studies. Environ. Health Perspect. 2007, 115, 989-995. [CrossRef] [PubMed]

9. Bell, M.L.; Ebisu, K.; Leaderer, B.P.; Gent, J.F.; Lee, H.J.; Koutrakis, P.; Wang, Y.; Dominici, F.; Peng, R.D. Associations of PM 2.5 constituents and sources with hospital admissions: Analysis of four counties in connecticut and Massachusetts (USA) for persons $\geq 65$ years of age. Environ. Health Perspect. 2014, 122, 138-144. [CrossRef]

10. Bell, M.L.; Belanger, K.; Ebisu, K.; Gent, J.F.; Lee, H.J.; Koutrakis, P.; Leaderer, B.P. Prenatal exposure to fine particulate matter and birth weight. Epidemiology 2010, 21, 884-891. [CrossRef]

11. Mar, T.F.; Larson, T.V.; Stier, R.A.; Claiborn, C.; Koenig, J.Q. An analysis of the association between respiratory symptoms in subjects with asthma and daily air pollution in Spokane, Washington. Inhal. Toxicol. 2004, 16, 809-815. [CrossRef]

12. Franklin, M.; Koutrakis, P.; Schwartz, J. The role of particle composition on the association between $\mathrm{PM}_{2.5}$ and mortality. Epidemiology 2008, 19, 680-689. [CrossRef]

13. Kioumourtzoglou, M.-A.; A Coull, B.; Dominici, F.; Koutrakis, P.; Schwartz, J.; Suh, H. The impact of source contribution uncertainty on the effects of source-specific $\mathrm{PM}_{2.5}$ on hospital admissions: A case study in Boston, MA. J. Expo. Sci. Environ. Epidemiol. 2014, 24, 365-371. [CrossRef] [PubMed]

14. Ryan, P.H.; Dihle, M.; Griffin, S.; Partridge, C.; Hilbert, T.J.; Taylor, R.; Adjei, S.; Lockey, J.E. Erionite in road gravel associated with interstitial and pleural changes-An occupational hazard in Western United States. J. Occup. Environ. Med. 2011, 53, 892-898. [CrossRef] [PubMed]

15. Pun, V.C.; Yu, I.T.-S.; Ho, K.-F.; Qiu, H.; Sun, Z.; Tian, L. Differential effects of source-specific particulate matter on emergency hospitalizations for ischemic heart disease in Hong Kong. Environ. Health Perspect. 2014, 122, 391-396. [CrossRef] [PubMed]

16. Zereini, F.; Alsenz, H.; Wiseman, C.L.; Püttmann, W.; Reimer, E.; Schleyer, R.; Bieber, E.; Wallasch, M. Platinum group elements $(\mathrm{Pt}, \mathrm{Pd}, \mathrm{Rh})$ in airborne particulate matter in rural vs. urban areas of Germany: Concentrations and spatial patterns of distribution. Sci. Total Environ. 2012, 416, 261-268. [CrossRef] [PubMed]

17. Ducret-Stich, R.E.; Tsai, M.-Y.; Thimmaiah, D.; Künzli, N.; Hopke, P.K.; Phuleria, H.C. PM 10 source apportionment in a Swiss Alpine valley impacted by highway traffic. Environ. Sci. Pollut. Res. 2013, 20, 6496-6508. [CrossRef] [PubMed]

18. Khan, R.K.; Strand, M.A. Road dust and its effect on human health: A literature review. Epidemiol. Health 2018, 40, e2018013. [CrossRef] [PubMed]

19. Alves, C.A.; Vicente, E.D.; Vicente, A.M.; Rienda, I.C.; Tomé, M.; Querol, X.; Amato, F.; Rienda, I.C. Loadings, chemical patterns and risks of inhalable road dust particles in an Atlantic city in the north of Portugal. Sci. Total Environ. 2020, 737, 139596. [CrossRef] [PubMed]

20. Jose, J.; Srimuruganandam, B. Investigation of road dust characteristics and its associated health risks from an urban environment. Environ. Geochem. Health 2020, 42, 2819-2840. [CrossRef]

21. Chen, S.; Zhang, X.; Lin, J.; Huang, J.; Zhao, D.; Yuan, T.; Huang, K.; Luo, Y.; Jia, Z.; Zang, Z.; et al. Fugitive road dust PM 2.5 emissions and their potential health impacts. Environ. Sci. Technol. 2019, 53, 8455-8465. [CrossRef]

22. Wu, X.; Nethery, R.C.; Sabath, B.M.; Braun, D.; Dominici, F. Exposure to air pollution and COVID-19 mortality in the United States: A nationwide cross-sectional study. medRxiv 2020. [CrossRef]

23. USDA. Fugitive Dust A Guide to the Control of Windblown Dust on Agricultural Lands in Nevada; USDA: Washington, DC, USA, 2007.

24. Succarieh, M. Control of Dust Emissions from Unpaved Roads; Washington, DC, USA, 1992. Available online: https://trid.trb.org/ view / 679675 (accessed on 21 June 2020).

25. Ashley, W.S.; Strader, S.; Dziubla, D.C.; Haberlie, A. Driving blind: Weather-related vision hazards and fatal motor vehicle crashes. Bull. Am. Meteorol. Soc. 2015, 96, 755-778. [CrossRef]

26. Ecola, L.; Popper, S.; Silberglitt, R.; Fraade-Blanar, L. The road to zero: A vision for achieving zero roadway deaths by 2050. Rand Health Q. 2018, 8, 11.

27. Jones, M. Plainfield Dust Storm: Crashes on Wisconsin I-39 Involve 37 Vehicles 2020. Available online: https:/ / www.jsonline. com/story/news/crime/2020/05/03/plainfield-dust-storm-crashes-wisconsin-39-involve-37-vehicles/3076039001/ (accessed on 21 June 2020).

28. Walsh, P. Dust May Have Been Factor in Fatal ATV Crash near Moose Lake. 2020. Available online: https:/ /www.startribune. com/dust-may-have-been-factor-in-fatal-atv-crash-near-moose-lake/571633802/ (accessed on 21 June 2020).

29. Parmer, J. Coroner Identifies Victims in Fatal Crash on Highway 41; Nexstar Broadcast Inc.: Irving, TX, USA, 2020. Available online: https:/ / www.yourcentralvalley.com/news/coroner-identifies-man-killed-on-fresno-highway-after-flipping-car/ (accessed on 21 June 2020).

30. Higgins, G.; Murray, D. Highway 87 between Great Falls and Fort Benton Closed due to High Winds. Great Falls Tribune, 1 February 2020.

31. Jones, D. Guideline for the Selection, Specification, Application of Chemical Dust Control and Stabilization Treatments on Unpaved Roads; University of California Pavement Research Center: Davis, CA, USA, 2017.

32. Ford, J.L.; Willson, R. Thermal Analysis and Calorimetry of Pharmaceuticals. In Handbook of Thermal Analysis and Calorimetry; Elsevier Science BV: Amsterdam, The Netherlands, 1999; Volume 4, pp. 923-1016. [CrossRef]

33. Pinterić, M. Building Physics: From Physical Principles to International Standards; Springer International Publishing: Berlin/Heidelberg, Germany, 2017. [CrossRef]

34. Zohuriaan-Mehr, M.; Kabiri, K. Superabsorbent polymer materials: A review. Iran Polym. J. 2008, 17, 451-477. 
35. Niazi, S. Handbook of Preformulation: Chemical, Biological, and Botanical Drugs, 2nd ed.; CRC Press: Boca Raton, FL, USA, 2019.

36. Mauer, L.J.; Taylor, L.S. Water-solids interactions: Deliquescence. Annu. Rev. Food Sci. Technol. 2010, 1, 41-63. [CrossRef] [PubMed]

37. Allan, M.C. Characterization of Water-Solid Interactions in Crystalline Ingredients and Development of Deliquescence Measurement Recommendations; Purdue University: West Lafayette, IN, USA, 2014.

38. Tereshchenko, A.G. Deliquescence: Hygroscopicity of water-soluble crystalline solids. J. Pharm. Sci. 2015, 104, 3639-3652. [CrossRef]

39. Yao, W.; Yu, X.; Lee, J.W.; Yuan, X.; Schmidt, S.J. Measuring the deliquescence point of crystalline sucrose as a function of temperature using a new automatic isotherm generator. Int. J. Food Prop. 2011, 14, 882-893. [CrossRef]

40. Du, L.; Wang, Z.; Li, S.; Song, W.; Lin, W. A comparison of monomeric phenols produced from lignin by fast pyrolysis and hydrothermal conversions. Int. J. Chem. React. Eng. 2013, 11, 135-145. [CrossRef]

41. Jin, H.; Nie, W.; Zhang, Y.; Wang, H.; Zhang, H.; Bao, Q.; Yan, J. Development of environmental friendly dust suppressant based on the modification of soybean protein isolate. Processes 2019, 7, 165. [CrossRef]

42. Okonkwo, E.M.; Ofoegbu, O. Renewable Eco-Friendly Material for Road Dust Suppression and Prevention. In Proceedings of the 2nd International Conference on Waste Management, Water Pollution, Air Pollution, Indoor Climate (MVAI'08), Corfu, Greece, 26-28 October 2008.

43. Andrew, W.; Joseph, P.; Mark, F. Control of Dust. U.S. Patent 6,790,245 2004, 14 September 2004.

44. Usher, J. Dust Suppressant. International Patent Classification(s) C09K. Australian Patent Office (54) (51) (21) (31) (43) (43) (71) (72) (74), 4 October 2008.

45. Gilmour, D. Dust Suppressant Comprising Microbes, 2013. World Intellectual Property Organization WO 2013/086611 Al, 12 December 2012.

46. Zhan, Q.; Qian, C.; Yi, H. Microbial-induced mineralization and cementation of fugitive dust and engineering application. Constr. Build Mater. 2016, 121, 437-444. [CrossRef]

47. Marco, D.C.A.; Cash, D.; Belden, L.K.; Blaustein, A.R.; Marco, A. Sensitivity to Urea Fertilization in Three Amphibian Species. Arch. Environ. Contam. Toxicol. 2001, 40, 406-409. [CrossRef] [PubMed]

48. Hamdan, N.; Kavazanjian, E. Enzyme-induced carbonate mineral precipitation for fugitive dust control. Geotechnique 2016, 66, 546-555. [CrossRef]

49. Dang, X.; Shan, Z.; Chen, H. Usability of oxidized corn starch-gelatin blends for suppression and prevention of dust. J. Appl. Polym. Sci. 2016, 134. [CrossRef]

50. Bao, Q.; Nie, W.; Liu, C.; Liu, Y.; Zhang, H.; Wang, H.; Jin, H. Preparation and characterization of a binary-graft-based, water-absorbing dust suppressant for coal transportation. J. Appl. Polym. Sci. 2019, 136. [CrossRef]

51. Lai, S.L. Preparation and Application of Polymer Dust Suppressants in Coal Transportation under Microwave Irradiation. Adv. Mater. Res. 2012, 396, 1632-1635. [CrossRef]

52. Chen, R.; Lee, I.; Zhang, L. Biopolymer stabilization of mine tailings for dust control. J. Geotech. Geoenvironmental Eng. 2015, 141, 04014100. [CrossRef]

53. Zhang, H.; Nie, W.; Wang, H.; Bao, Q.; Jin, H.; Liu, Y. Preparation and experimental dust suppression performance characterization of a novel guar gum-modification-based environmentally-friendly degradable dust suppressant. Powder Technol. 2018, 339, 314-325. [CrossRef]

54. Liu, Y.; Nie, W.; Jin, H.; Ma, H.; Hua, Y.; Cai, P.; Wei, W. Solidifying dust suppressant based on modified chitosan and experimental study on its dust suppression performance. Adsorpt. Sci. Technol. 2018, 36, 640-654. [CrossRef]

55. Raab, M.T.; Segal, W.A. Chitosan Coagulant as a Binder and Dust Control Agent Field of The Invention. U.S. Patent Application 16/098,676, 16 May 2019.

56. Lee, T.; Park, J.; Knoff, D.S.; Kim, K.; Kim, M. Liquid amphiphilic polymer for effective airborne dust suppression. RSC Adv. 2019, 9, 40146-40151. [CrossRef]

57. Niaounakis, M. Biopolymers: Applications and Trends; William Andrew: Norwich, NY, USA, 2015.

58. Kim, D.; Quinlan, M.; Yen, T.F. Encapsulation of lead from hazardous CRT glass wastes using biopolymer cross-linked concrete systems. Waste Manag. 2009, 29, 321-328. [CrossRef]

59. Niaounakis, M.; Halvadakis, C.P. Olive Processing Waste Management: Literature Review and Patent Survey, Google Books; Pergamon: Bergama, Turkey, 2006.

60. Fan, W.W.; Zhu, D.-W.; Zhu, Q.; Jacobs, J.L.; Morris, M.L.; Reynolds, K.K.; Tang, U.N. Dust suppressants. European Patent Office EP2393898A2, 8 February 2010.

61. Inyang, H.I.; Bae, S.; Pando, M.A. Contaminant dust suppression materials: A cost-effectiveness estimation methodology. Measurement 2016, 93, 563-571. [CrossRef]

62. Devi, R.M.; Madhavan, N.; Bhattacharyya, A.; Arumugum, N. Dust Suppressant Compositions, Methods for Making and Methods for Using. World Intellectual Property Organization WO 2013/108057 Al, 25 July 2013.

63. Liao, Q.; Feng, G.; Fan, Y.; Hu, S.; Shao, H.; Huang, Y. Experimental investigations and field applications of chemical suppressants for dust control in coal mines. Adv. Mater. Sci. Eng. 2018, 2018, 1-9. [CrossRef]

64. Norman, M.; Johansson, C. Studies of some measures to reduce road dust emissions from paved roads in Scandinavia. Atmos. Environ. 2006, 40, 6154-6164. [CrossRef] 
65. Amato, F.; Escrig, A.; Sanfelix, V.; Celades, I.; Reche, C.; Monfort, E.; Querol, X. Effects of water and CMA in mitigating industrial road dust resuspension. Atmos. Environ. 2016, 131, 334-340. [CrossRef]

66. Barratt, B.; Carslaw, D.; Fuller, G.; Green, D.; Tremper, A. Evaluation of the Impact of Dust Suppressant Application on Ambient PM10 Concentrations along 'Hot Spot' Highway Corridors; Kings College London, University of London: London, UK, 2012.

67. Amato, F.; Karanasiou, A.; Cordoba, P.; Alastuey, A.; Moreno, T.; Lucarelli, F.; Nava, S.; Calzolai, G.; Querol, X. Effects of road dust suppressants on PM levels in a mediterranean urban area. Environ. Sci. Technol. 2014, 48, 8069-8077. [CrossRef]

68. Sanders, T.G.; Addo, J.Q.; Ariniello, A.; Heiden, W.F. Relative effectiveness of road dust suppressants. J. Transp. Eng. 1997, 123, 393-397. [CrossRef]

69. Elsholz, C. Dust Suppressant Use and Alternatives at Carnegie State Vehicular Recreation Area; Off-Highway Motor Vehicle Recreation Division Department of Parks and Recreation State of California: Sacramento, CA, USA, 2012.

70. Breum, N.; Birgitte, N.; Merete, L.; Uffe, M. Dustiness of chopped straw as affected by lignosulfonate as a dust suppressant. Ann. Agric. Environ. Med. 1999, 6, 133-140. [PubMed]

71. Sanders, T.G.; Quayenortey, J.A.; Jorgensen, D. Unpaved road dust control in the Piceance creek basin in Rio Blanco county, Colorado. J. Transp. Eng. 2015, 141, 04014079. [CrossRef]

72. Du Plessis, J.J.L.; Janse van Rensburg, L.; Jansen van Rensburg, L.P. Effectiveness of Applying Dust Suppression Palliatives on Haul Roads; Mine Ventilation Society of South Africa: Randburg, South Africa, 2016.

73. Gotosa, J.; Nyamadzawo, G.; Mtetwa, T.; Kanda, A.; Dudu, V. Comparative Road Dust Suppression Capacity of Molasses Stillage and Water on Gravel Road in Zimbabwe. Adv. Res. 2015, 3, 198-208. [CrossRef]

74. Fan, T.; Zhou, G.; Wang, J. Preparation and characterization of a wetting-agglomeration-based hybrid coal dust suppressant. Process. Saf. Environ. Prot. 2018, 113, 282-291. [CrossRef]

75. Sanders, T.G.; Addo, J.Q. Effectiveness and Environmental Impact of Road Dust Suppressants; The National Academies of Sciences, Engineering, and Medicine: Washington, DC, USA, 1993.

76. Gustafsson, M.; Johansson, C. Road pavements and $\mathrm{PM}_{10}$ : Summary of the Results of Research Funded by the Swedish Transport Administration on How the Properties of Road Pavements Influence Emissions and the Properties of Wear Particles n.d. Available online: www.diva-portal.org/smash/record.jsf?pid=diva2\%3A674206\&dswid=1062 (accessed on 31 January 2021).

77. Flatt, R.J.; Schober, I. Superplasticizers and the Rheology of Concrete. In Understanding the rheology of concrete; Woodhead Publishing: Cambridge, UK, 2012; pp. 144-208. [CrossRef]

78. Han, C. Dust Control on Unpaved Roads. 1992. Available online: http://www.dot.state.mn.us/research/pdf/1992-07.pdf (accessed on 21 June 2020).

79. Sajid, H.U.; Kiran, R. Influence of corrosion and surface roughness on wettability of ASTM A36 steels. J. Constr. Steel Res. 2018, 144, 310-326. [CrossRef]

80. Sajid, H.U.; Kiran, R.; Qi, X.; Bajwa, D.S.; Battocchi, D. Employing corn derived products to reduce the corrosivity of pavement deicing materials. Constr. Build. Mater. 2020, 263, 120662. [CrossRef]

81. Edvardsson, K. Evaluation of Dust Suppressants for Gravel Roads: Methods Development and Efficiency Studies. Ph.D. Thesis, KTH Royal Institute of Technology, Stockholm, Sweden, 21 April 2010.

82. Cotter, J. Start Flank on Delvery Vehicle with Expred Beverages. U.S. Patent US 2008/00873.05 A1, 2008.

83. Dixon-Hardy, D.W.; Beyhan, S.; Ediz, I.G.; Erarslan, K. The use of oil refinery wastes as a dust suppression surfactant for use in Mining. Environ. Eng. Sci. 2008, 25, 1189-1196. [CrossRef]

84. Hey, S.M.; Adkins, S.; Neale, M.G.; Stocks, P. Dust suppression and Reduction of Surface Oxidation for Mineral Agglomerates. U.S. Patent 2008/0028890 A1, 4 December 2008.

85. Medeiros, M.A.; Leite, C.M.M.; Lago, R.M. Use of glycerol by-product of biodiesel to produce an efficient dust suppressant. Chem. Eng. J. 2012, 180, 364-369. [CrossRef]

86. Gillies, J.A.; Watson, J.G.; Rogers, C.F.; Dubois, D.; Chow, J.C.; Langston, R.; Sweet, J. Long-term efficiencies of dust suppressants to reduce $\mathrm{PM}_{10}$ emissions from unpaved roads. J. Air Waste Manag. Assoc. 1999, 49, 3-16. [CrossRef] [PubMed]

87. Cui, D.; Baisheng, N.; Hua, Y.; Linchao, D.; Caihong, Z.; Fei, Z.; Hailong, L. Experimental research on optimization and coal dust suppression performance of magnetized surfactant solution. Procedia Eng. 2011, 26, 1314-1321. [CrossRef]

88. Xi, Z.; Jiang, M.; Yang, J.; Tu, X. Experimental study on advantages of foam-Sol in coal dust control. Process. Saf. Environ. Prot. 2014, 92, 637-644. [CrossRef]

89. O’Brien, K.; Ergang, N.S.; Bhattacharja, S.; Brinkmeier, A.; Cranfill, J.C., III; Lendrum, S.P. Methods of and Systems for Controling Dust. U.S. Patent 2017/013.0109 A1, 11 May 2017.

90. Goodrich, B.A.; Koski, R.D.; Jacobi, W.R. Monitoring surface water chemistry near magnesium chloride dust suppressant treated roads in Colorado. J. Environ. Qual. 2009, 38, 2373-2381. [CrossRef] [PubMed] 